\title{
Utilizing Geospatial Tools to Assign Unique Identifiers to Water Bodies in a Low-Income Country
}

\author{
Abubakarr S. Mansaray ${ }^{1}$, Abdulai Barrie ${ }^{2}$, Eva B. M. Jabati³, Mohamed S. E. Juanah", \\ Kyran J. Ganda ${ }^{3}$
}

${ }^{1}$ Oklahoma Water Resources Center, Division of Agricultural Science and Natural Resources, Oklahoma State University, Stillwater, Oklahoma, USA

${ }^{2}$ Energy Sector Utility Reform Project, Energy Distribution and Supply Authority, Government of Sierra Leone, Freetown, Sierra Leone

${ }^{3}$ Institute of Environmental Management and Quality Control, School of Environmental Science, Njala University, Njala, Sierra Leone

${ }^{4}$ National Water Resource Management Agency, Government of Sierra Leone, Freetown, Sierra Leone

Email: *abu.mansaray@okstate.edu

How to cite this paper: Mansaray, A.S., Barrie, A., Jabati, E.B.M, Juanah, M.S.E. and Ganda, K.J. (2021) Utilizing Geospatial Tools to Assign Unique Identifiers to Water Bodies in a Low-Income Country. Journal of Water Resource and Protection, 13, 236-253.

https://doi.org/10.4236/jwarp.2021.133014

Received: January 29, 2021

Accepted: March 13, 2021

Published: March 16, 2021

Copyright $\odot 2021$ by author(s) and Scientific Research Publishing Inc. This work is licensed under the Creative Commons Attribution International License (CC BY 4.0).

http://creativecommons.org/licenses/by/4.0/ (c) (i) Open Access

\begin{abstract}
Inland waters support the growth of several sectors including mining, agriculture, and health. This makes it crucial to have sustainable quantity and quality through conservation practices. Achieving sustainability requires information on the spatial distribution of water bodies. This requirement is particularly critical in low-income nations where dependence on natural resources is a key driver to economic growth. Unfortunately, these nations lack the resources to promote costly waterbody characterization. This study presents a cost-effective approach in assigning Unique Identifiers (UIDs) that define locations and characteristics of rivers and streams. Our objective is to develop a scheme that can be used to identify and characterize rivers and streams in a nation. We utilized an open-source Digital Elevation Model (DEM) of NASA's ASTER satellite and the hydrology tool in ArcGIS 10.7.1. The DEM was imported to ArcGIS followed by delineation of hydrologic regions, subregions, and stream orders. Each stream segment was given a UID based on its region and Strahler's stream order system. We present a case study analysis for two regions within Sierra Leone using water quality data of selected rivers and streams. These will lay the foundation for a nationwide coding exercise and provide a useful reference for water resource practitioners.
\end{abstract}

\section{Keywords}

River, Stream, Unique Identifier, Remote Sensing, GIS, Water Quality 


\section{Introduction}

Inland water bodies provide development opportunities in sectors such as agriculture, energy, transportation, health and sanitation, housing, and recreation [1]. Conservation of these water bodies is crucial to achieve sustainable quantity and quality as well as tradeoffs that benefit populations, their economies, and natural ecosystems [2]. A key to achieving these goals is having adequate information on the spatial distribution of these freshwater resources.

Assigning Unique Identifiers (UIDs) to water bodies that contribute to downstream ecosystems allows for tracking the sources of water quality issues. A 2007 study found that $65 \%$ of the nitrogen flux in downstream water bodies was contributed by second-order streams, $55 \%$ by fourth-order rivers, and $40 \%$ by higher-order rivers [3]. Information on the locations of tributaries also provides the ability to study the spatial and temporal dynamics of aquatic biodiversity in a basin. This information can help us study species migration patterns during different stages of development as well as delineating their permanent or seasonal locations and localizations [4]. These give us the ability to design sampling approaches that ensure water quality monitoring programs that can help successful water quality management [5].

Unique identifiers of rivers and streams guide the establishment of gauging networks through which the pulse of a nation's flowing waters can be monitored [6]. Stream gauging networks help water resource managers achieve several benefits including allocation for irrigation, flood forecasting, climate change impact assessments, and rural/urban water supply planning [7]. Moreover, the data from all gauging stations in a monitoring network provide information on the total renewable surface freshwater resources in a nation [8].

Assigning Water Body IDs (WBIDs) is particularly important in low-income countries where dependence on natural resources is a key driver of economic growth [9]. The World Bank defines low-income countries as those with a Gross National Income (GNI) per capita of $\$ 1035.00$ or less [10]. Sierra Leone is an example of a nation that meets this definition with GNI per capita of $\$ 540.00$ [10].

The Food and Agricultural Organization (FAO) estimates Sierra Leone's total renewable water resources as $160 \mathrm{~km}^{3} /$ year, with surface water accounting for $150 \mathrm{~km}^{3} /$ year [11]. In a 2008 study, this quantity was estimated to be $59.3-98.4$ $\mathrm{km}^{3} /$ year (32\% - 54\% of mean annual rainfall) [12]. A 1999 report characterized Sierra Leone's drainage systems as dense and having nine major river basins; 1) the Great Scarcies (also called the Kolente), 2) Little Scarcies, 3) Rokel (also called the Seli), 4) Gbangbaia, 5) Jong, 6) Sewa, 7) Waanje, 8) Moa, and 9) Mano [13]. Another classification scheme divided the nation's waters into 11 major river basins. Five were classified as main rivers (Little Scarcies, Rokel, Jong, Sewa and Moa) and the remaining six as smaller basins and drainage areas (Great Scarcies, Lokko, Rokel Estuary, Western, Robbi/Thauka, and Sherbro Water Resources Areas) [8]. 
Although these statistics provide useful estimates that may inform water resource planning and policy, they are not detailed enough to support sustainable growth in sectors that depend on the resource. There is no identification system that details the tributaries that contribute to major rivers in Sierra Leone. The agencies responsible for the management of water resources are limited in resources, preventing them from carrying out nationwide ground-based data gathering for such detailed characterization. Nonetheless, an identification system is needed to guide water resource monitoring designs and sustainable water resource management.

The availability of data from remote sensing and Geographic Information Systems (GIS) provide the opportunity to achieve this goal in a cost-effective manner. Satellite derived Digital Elevation Models (DEMs) and GIS software packages can be utilized to delineate national drainage systems, which can then be calibrated and validated by ground truth data. These datasets can be used to assign UIDs to the nation's rivers and streams based on hydrologic regions and subregions [14] [15] [16].

Codifying water bodies is an active practice in water resource management. In the United States and the Caribbean, for example, waters have been classified using a national standard hierarchical system that is based on surface hydrologic features. This classification system is broken into four types of hydrologic units: 1) regions, 2) sub-regions, 3) accounting units, and 4) cataloguing units [17]. Each water body has a unique code that defines its location and characteristics. This has enhanced informed decision making on water resources for the populations that depend on the resource.

We present a method to assign UIDs to inland water bodies, guide better planning and policy, and maximize conservation of those inland water bodies in low-income countries. Our objective is to develop a scheme that can be used to identify and characterize rivers and streams in Sierra Leone. We present case study analyses for two regions within Sierra Leone using ground truth water quality data of selected rivers and streams. These will lay the foundation for a nationwide classification and coding exercise for waters in the country and provide a useful reference for water resource practitioners in low-income nations.

\section{Materials and Methods}

\section{Description of the Study Area}

Sierra Leone is located on the west coast of Africa sharing boarders with Guinea in the northeast, Liberia in the southeast, and the Atlantic Ocean in the west. It has a total land area of about $72,000 \mathrm{~km}^{3}$ [18]. Figure 1 presents a map of Sierra Leone showing its elevations above sea level.

Sierra Leone has four physical regions: the Coastal Plains, the Freetown Peninsula, the Interior Lowlands, and the Interior Plateau [13]. The Coastal Plains are about $320 \mathrm{~km}$ long, comprised mainly of low elevation wetlands that are adjacent to the Atlantic Ocean. The maximum width is $40 \mathrm{~km}$, and they have many 


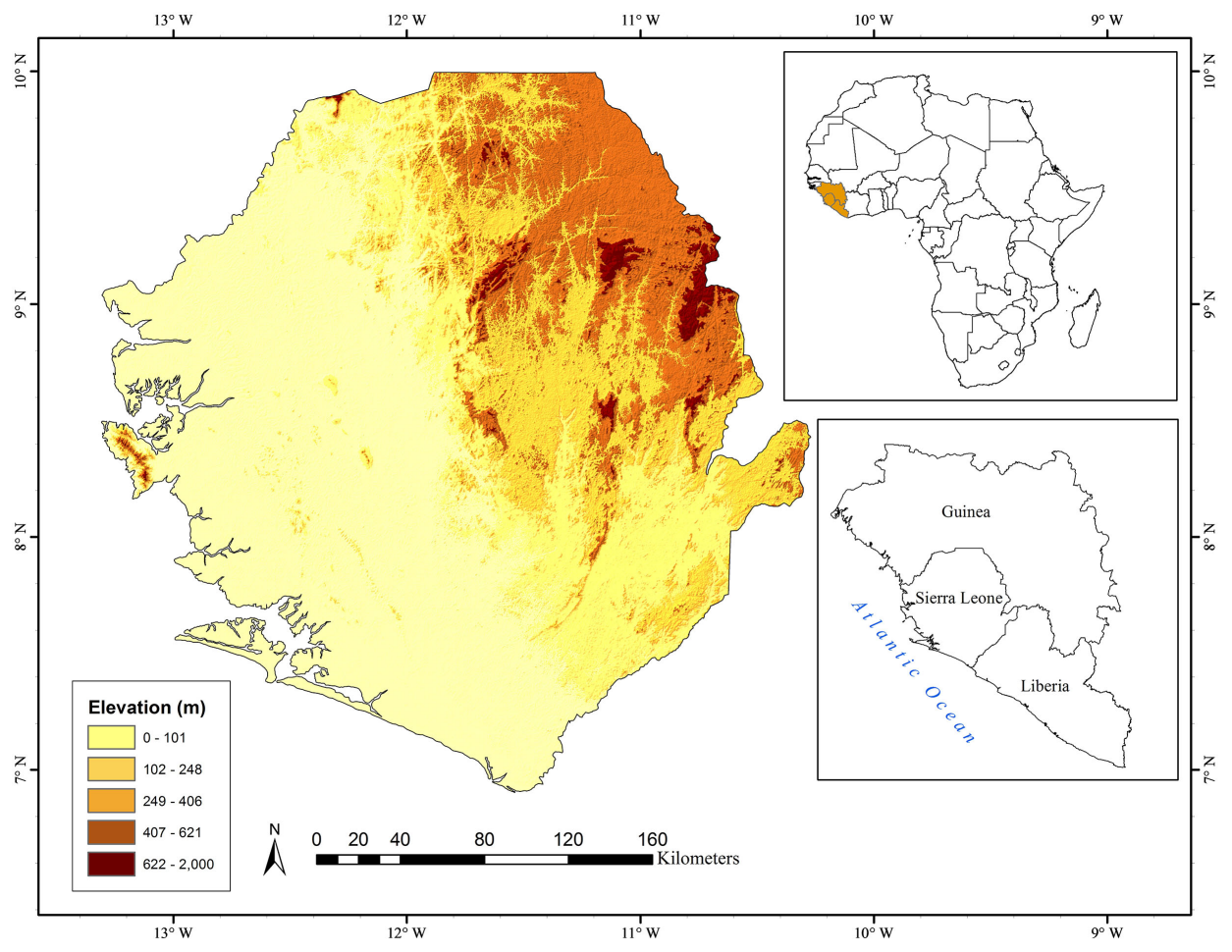

Figure 1. Map of Sierra Leone showing its neighboring countries (Guinea and Liberia) in Africa and elevations above sea level. These elevations were delineated using Global DEM data collected by NASA's ASTER satellite sensor.

creeks that run through mangrove swamps into the ocean. The Freetown Peninsula is about $40 \mathrm{~km}$ long and is south of Freetown with hills and mountain ranges of up to $900 \mathrm{~m}$ above the coast. The Interior Lowlands are mostly swamps in the north and isolated hills as high as $300 \mathrm{~m}$ in the south. The Interior Plateau region is characterized by elevations as high as about $2000 \mathrm{~m}$ above sea level with a tropical rain forest in the northeast [13]. All the rivers flow southwest into the Atlantic Ocean [19].

\section{Assigning WBIDs Using Remotely Sensed Data and GIS}

Open-source DEM data were acquired by the Advanced Spaceborne Thermal Emission and Reflection Radiometer (ASTER) and made available as Global DEM (GDEM) version 3 at the Earth-data search website of NASA. The DEM has 16-bit signed integer data in a simple binary raster. It provides a GDEM of land areas on Earth at a spatial resolution of 1 arc-second (approximately 30-meter horizontal posting at the equator). Each DEM tile was given in a GeoTIFF format and projected on the 1984 World Geodetic System (WGS84) [20]. We downloaded the ASTER GDEM files and imported them into ArcMap 10.7.1 to map the rivers and streams in the study area.

This study utilized the hydrologic analysis function in ArcMap 10.7.1 to model the movement of rivers and streams in the study area. The tool has several functions that convert a DEM to stream networks within river basins. Those uti- 
lized in this study were the Fill, Flow Direction, Flow Accumulation, Basin, Stream Order, Map Algebra, and Stream to Feature functions [21]. These tools transformed the ASTER GDEM pixels into drainage networks that were grouped into basins. The workflow followed conversion of the DEM to a Fill surface raster file, which was then used to generate Flow Direction and Flow Accumulations raster files. The Flow Direction file was used to divide the nation into hydrologic regions and subregions, similar to the 12-basin system developed in a previous work [8]. Figure 2 presents a flow diagram of the step-by-step procedures followed to delineate the regions and streams.

The Flow Accumulation file was brought into the Raster Calculator function in Map Algebra to convert the raster cells into stream networks. The Stream Order tool categorized these streams into cumulative orders. The Stream to Feature function was then used to convert this raster file into a stream vector file with nodes, grid codes, and ArcIDs. The grid codes, which are lines between nodes, were ranked based on their original pixel values and each grid code was assigned a UID called ArcID. We designated the grid codes as stream levels (based on their respective stream orders) along the flow direction. These stream levels formed part of the WBIDs for to the river and stream segments in the study area.

We utilized the Strahler's stream ordering system to assign UIDs to rivers and streams. Strahler's ordering system is a top-bottom classification scheme based on river-tributary relationships. In the system, first order streams are headwater channels with no upstream tributaries and second order streams form below the confluence of two first-order channels. Third order streams form when two

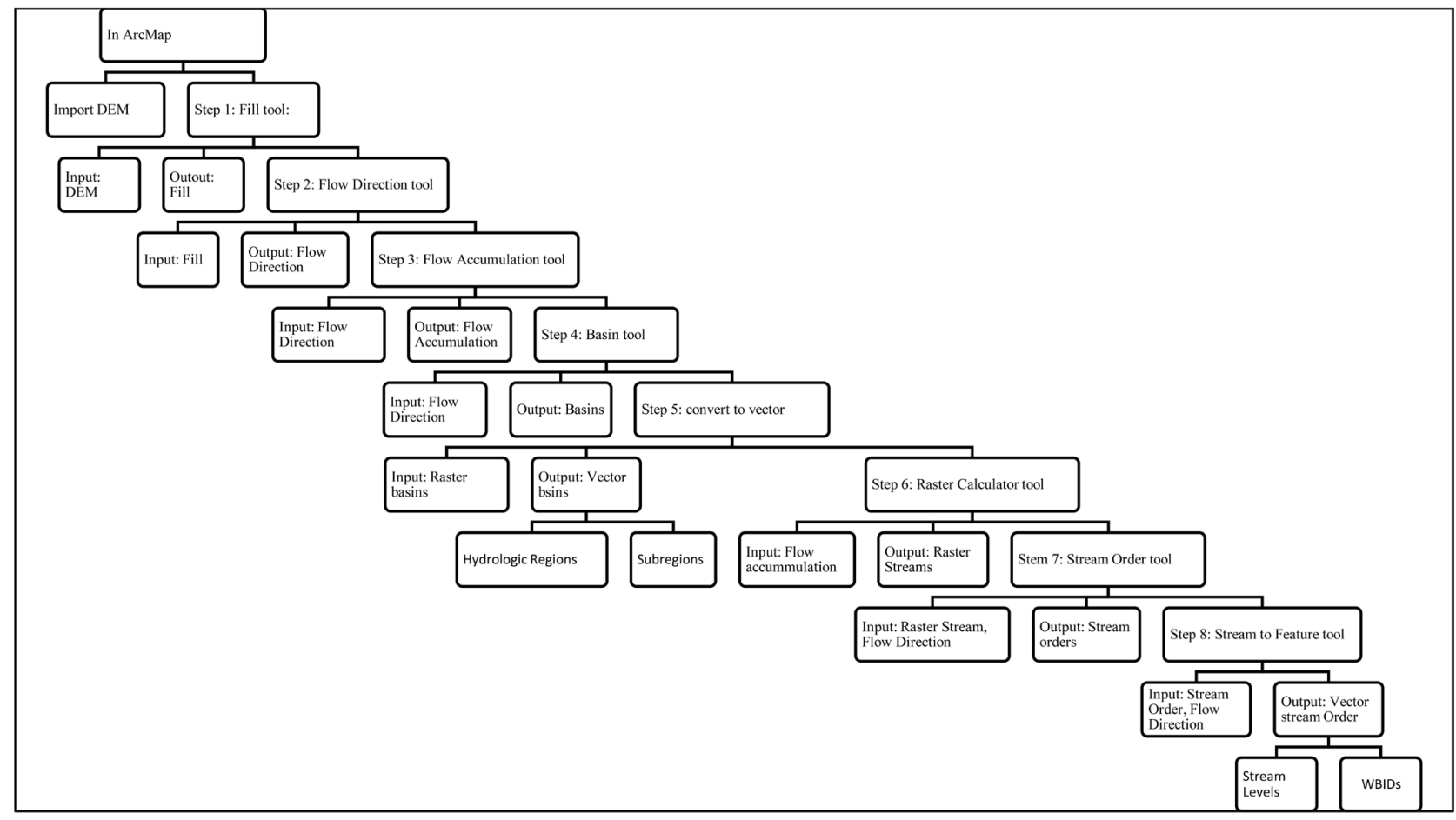

Figure 2. Flow diagram showing the steps in delineating hydrologic regions, sub regions, and stream orders. 
second order channels join. This tree system continues as two orders of the same magnitude converge to form a higher order stream [22]. All first order streams were classified as Level 1 (L1) streams, second order streams were classified as Level 2 (L2) streams, and so on.

Major river basins were classified as hydrologic regions and further divided into subregions, which are watersheds within each region. We gave an arbitrary total of 16-digits to each WBID. The first four digits represent the hydrologic region (e.g., HR01); digits 5-8 represent the subregion (e.g., HR01W001); digits 9-10 represent the stream level (e.g., HR01W001L1); and the last six represent the unique number (ArcID) of each stream segment (e.g., HR01W001L1000001).

When streams in the same subregion and with the same level have branches that connect to form a higher level, each branch and the new level will have a unique WBID. For example, two L4 Streams in HR02W001 would have WBIDs HR02W001L4000001 and HR02W001L4000002, while the emerging higher order stream will have WBID HR02W001L5000001.

\subsection{Case Study Analysis}

\subsubsection{Water Quality Data}

This study utilized ground truth water quality data in selected streams and rivers of the study area. Water quality samples were collected in two of the hydrologic regions delineated in this study. The WBIDs for the stream/river segments matching those sample sites are defined and presented.

In the first region, one year of water quality data for physical (temperature and turbidity) and chemical (dissolved oxygen (DO) and orthophosphates $\left(\mathrm{PO}_{4}^{3-}\right)$ ) parameters were used to ground truth WBIDs at 19 sample sites. Figure 3 shows a map of the Rokel basin, the region utilized for the physical and chemical analyses.

\subsubsection{Physical and Chemical Parameters}

The temperature in rivers is important to the health of aquatic organisms as a key component in metabolic pathways [23] [24]. Change in diurnal temperatures influences the rate of microbial degradation of organic carbon, leading to consumption of DO as a terminal electron acceptor, which impacts the survival of aquatic organisms [24]. Turbidity impacts light penetration in the water, which influences primary productivity [25]. Phosphates are also related to redox conditions in the water body. In oxygenated water, $\mathrm{PO}_{4}^{3-}$ tend to bind to iron and become sequestered in the sediment and become bioavailable again during anoxic conditions [26].

These physical and chemical parameters were sampled at monthly intervals over a period of eight months (December 2019 to August 2020) in the Rokel River and its tributaries along the basin (Figure 3). These months divide into two seasons in the study area. The rainy season lasts from May to early November with a total rainfall up to $3000 \mathrm{~mm}$ and the dry season lasts from Late November to April with a total rainfall of about $150 \mathrm{~mm}$. 


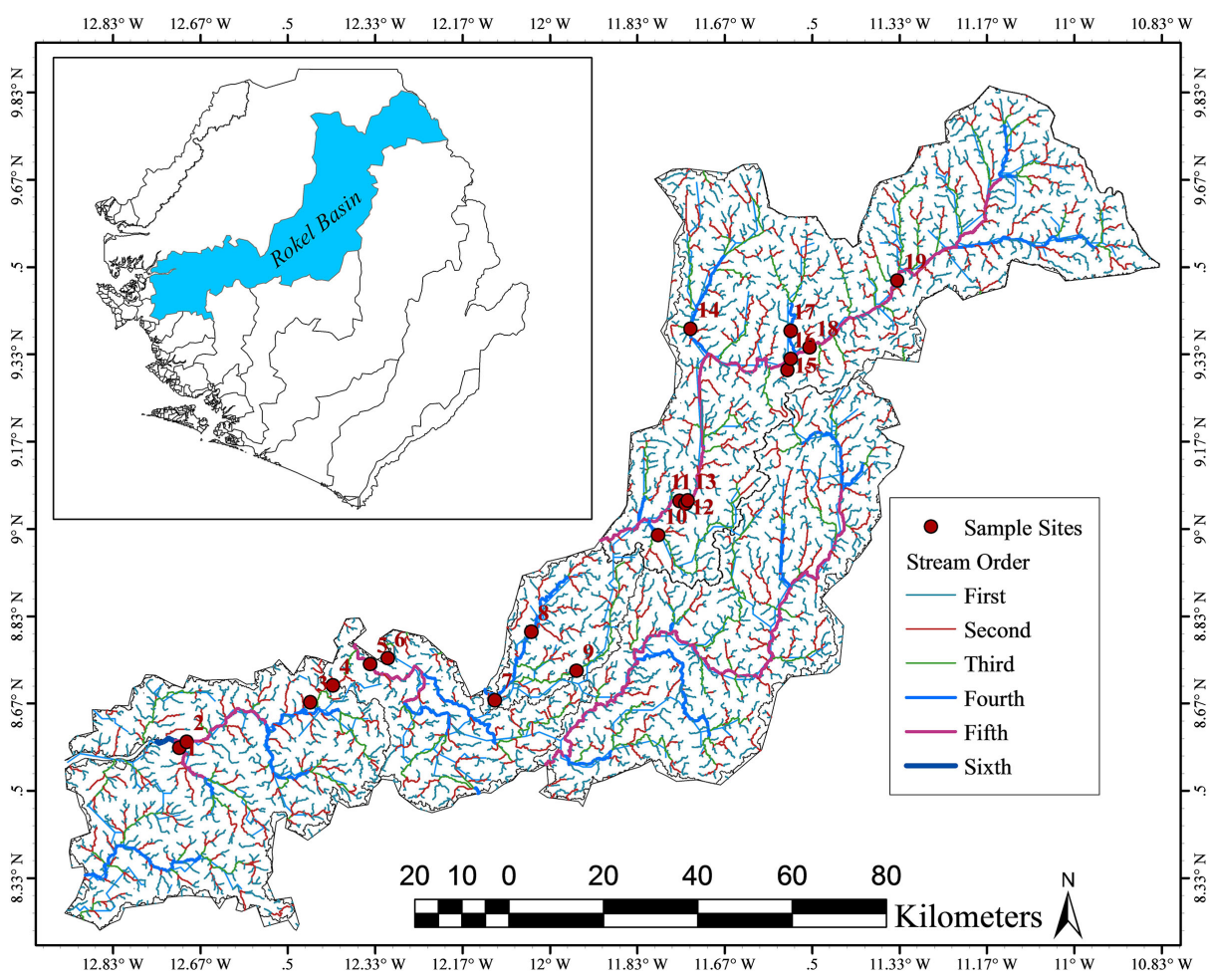

Figure 3. Map of the Rokel basin showing stream orders and water quality sampling sites. The data were collected by the NWRMA water quality monitoring program.

The water samples were tested on site with the Lovibond photometer MD610 for turbidity and $\mathrm{PO}_{4}^{3-}$; with the Lovibond SD 70 for temperature; and with the Eutech 2700 for DO. Samples were collected with sampling bottles at the surface $(0-20 \mathrm{~cm})$. The sampling bottles were rinsed three times with the river water and then positioned to allow the river water to flow in and fill the bottle.

Turbidity was measured in Nephelometric Turbidity Units (NTU). The instrument was calibrated using deionized water and standard solutions. High density polyethylene sampling bottles were used to collect the water sample after following rinsing procedures. A vial was filled with $10 \mathrm{~mL}$ of the sample and placed in the sample chamber of the instrument for turbidity readings.

To measure $\mathrm{PO}_{4}^{3-}$, a clean vial was filled with $10 \mathrm{~mL}$ of the water sample, capped, and placed in the sample chamber for zeroing. Another clean vial was filled with $10 \mathrm{~mL}$ of the water sample; one $\mathrm{PO}_{4}^{3-}$ No. $1 \mathrm{LR}$ and one $\mathrm{PO}_{4}^{3-}$ No. 2 LR tablet were added to the sample water and dissolved using the stirring rod. The capped vial was placed in the sample chamber and the test key activated for a reaction time of 10 minutes. After the reaction period was finished, the measurement automatically started.

For the determination of DO, the instrument was powered on and the mg/L mode selected. The probe was then fully immersed in the sample water and reading recoded when the READY indicator was displayed on the screen. Temperature was measured by fully immersing the probe of the instrument in the water and the reading recorded. 


\subsubsection{Benthic Macroinvertebrates}

Benthic macro invertebrates are small aquatic animals and the aquatic larval stages of insects commonly used as biological indicators of water quality in water bodies [27]. The presence or absence of these organisms are proven indicators of various forms of water quality [28]. They are reliable indicators because they spend all or most of their lives in water, are easy to collect, and differ in their tolerance to changes in water chemistry [29].

We collected benthic macroinvertebrate samples in eight streams in the western area of Sierra Leone, one of the designated hydrologic regions in the study area. A hand-made kick net was used to trap the macroinvertebrates. The kicknet was made with a $1-\mathrm{mm}$ mesh cloth attached to a $30-\mathrm{cm}$ circular wooden frame and the entire setup was $50 \mathrm{~cm}$ deep. These were attached to a $10-\mathrm{m}$ wooden handle to enable anchoring and control during sampling. A GPS unit was used to pin the sample locations; these were mostly in riffle areas that had rocks and debris, which are conducive habitats for macroinvertebrates [30].

We positioned the kick-net on the floor of the stream and ensured that it was open to incoming flowing water. We then made several kicks and disturbances upstream of the net to drive macroinvertebrate migration into the net. This was repeated over a distance of $20 \mathrm{~m}$ in each stream and the aggregate samples were placed in $500-\mathrm{mL}$ sample bottles filled with $90 \%$ ethanol to hold for transportation to the lab.

In the lab, we used forceps to transfer the macroinvertebrates to $250-\mathrm{mL}$ bottles that were filled with $100-\mathrm{mL}$ of ethanol (90\%) to preserve the samples. A magnifying hand lens was used to identify the macroinvertebrates at the Genus level in the Linnaeus classification system [31]. The identified taxa were recorded in tables with name description and sensitivity to pollution. The GPS coordinates of each sample site was recorded and used to validate WBIDs indicated on the maps generated with the ArcGIS hydrology tool. Figure 4 shows Macroinvertebrate sample sites in the Western Area of Sierra Leone.

\section{Results}

\subsection{Hydrologic Regions and Subregions}

The entire nation was divided into 12 hydrologic regions (HR01-HR12). These regions represent major river basins similar to those delineated in a previous report [8]. The order of numbering the regions was arbitrary and it trends from northwest to southeast. Figure 5 shows a map of Sierra Leone divided into the 12 hydrologic regions delineated in this study.

Figure 5 also shows the two case study regions that were divided into subregions. The GIS mapping tool divided the 30-m spatial resolution ASTER GDEM into seven subregions in HR04 (the Rokel River basin) and 21 subregions in HR05 (Western Area). Region 5 has many subregions because of the rugged terrain in the region [13]. 


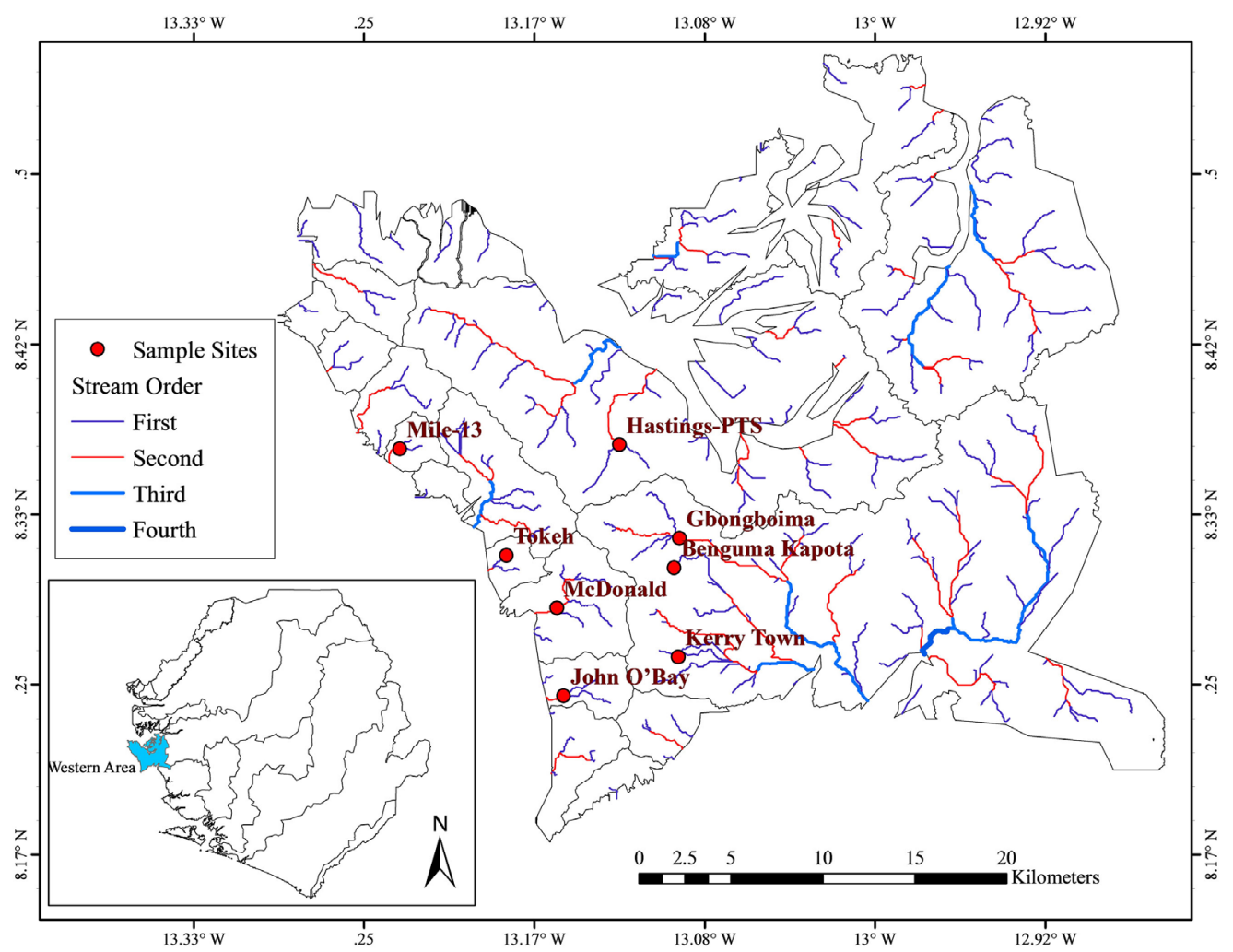

Figure 4. Macroinvertebrate sample sites in the Western Area of Sierra Leone.
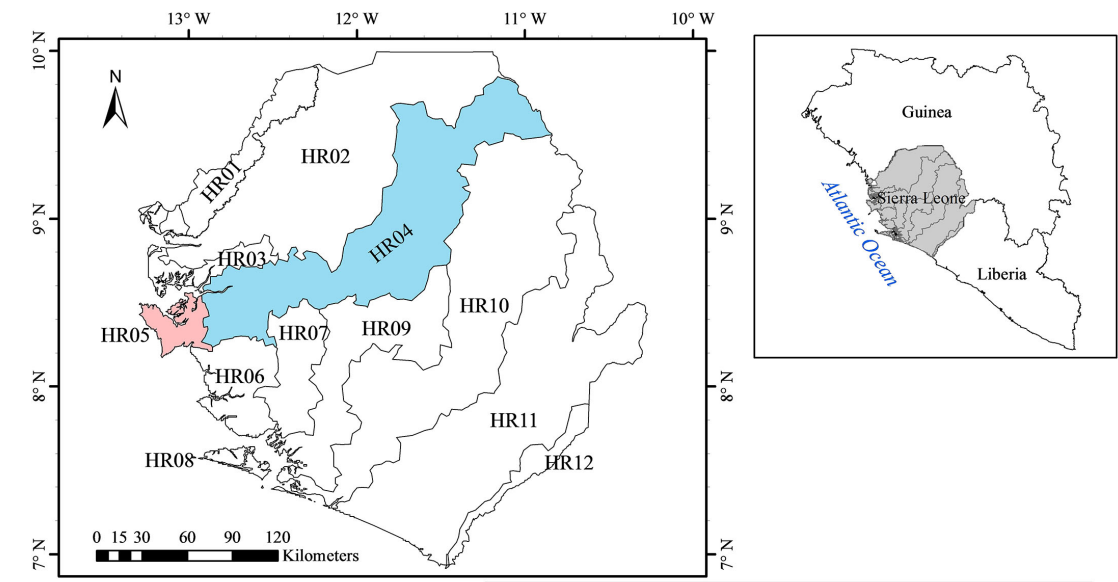

$\sum_{\infty}$
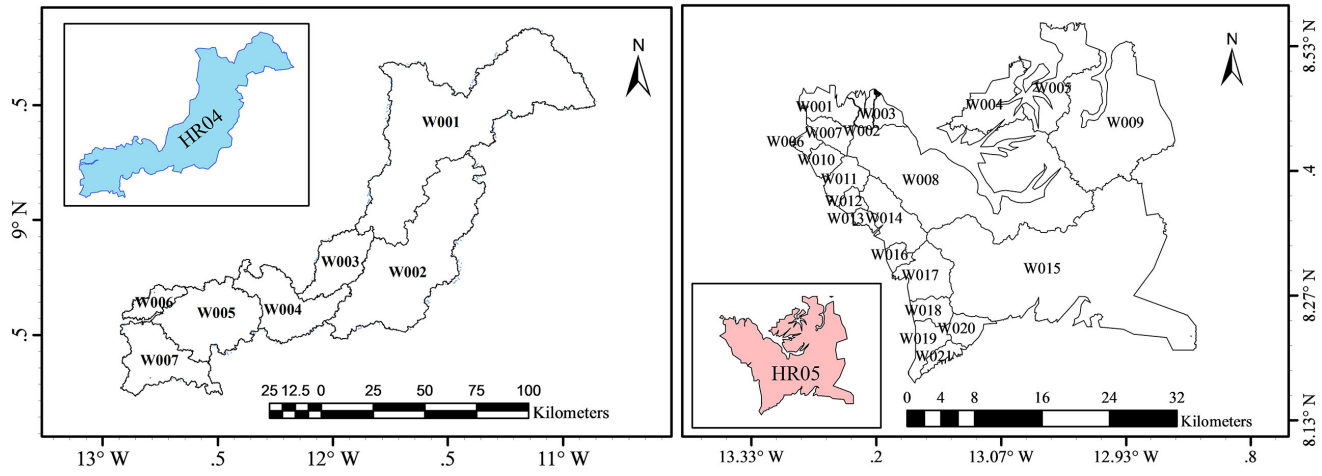

Figure 5. Map of Sierra Leone showing the hydrologic regions and the two case study regions (HR04 \& HR05) with their subregions. 


\subsection{Case Study Analysis}

\subsubsection{Physical and Chemical Parameters in HR04}

Figure 6 shows the readings obtained for temperature, turbidity, $\mathrm{DO}$, and $\mathrm{PO}_{4}^{3-}$ in HR04 during the study period.

Temperature ranged from $20^{\circ} \mathrm{C}$ to $37^{\circ} \mathrm{C}$ and fluctuated mostly between $25^{\circ} \mathrm{C}$ and $30^{\circ} \mathrm{C}$. This observation is consistent with the river temperatures $\left(>25^{\circ} \mathrm{C}\right)$ reported in tropical regions [32]. Turbidity is mostly in the $0-20$ NTU range. The few high readings may reflect surface runoff that brings in sediments from mine sites and tillage areas. Values of DO range mostly from 6.0 to 9.0. The DO range is within the acceptable limits $(6-12 \mathrm{mg} / \mathrm{L})$ stipulated in the SDG 6.3.2 recommendations for ambient water quality. Phosphates ranged from $0.08 \mathrm{mg} / \mathrm{L}$ to $4.0 \mathrm{mg} / \mathrm{L}$. These values are in violation of the recommended mean annual SDG 6.3.2 threshold of $0.035 \mathrm{mg} / \mathrm{L}$ [33]. This implies that further study is needed to trace the source of these high $\mathrm{PO}_{4}^{3-}$ levels and guide effective management strategies.

Figure 7 shows variations in the four paramters across time and space. The $y$-axis represents sample sites with the highest value (Site 19) corresponding to upstream and the lowest (Site 1), corresponding to downstream of HR04 (Figure 2). The $\mathrm{x}$-axis represents sample dates; the left side of the figure has dry season months (December-April) and the right side has wet season months (May-August).

Temperature was higher at downstream sites than upstream sites. This is expected because there are more human influences on the river in the downstream area, compared to upstream areas. The upstream areas are forested and hilly with small villages sparsely distributed in the forests (Sites 13-20). The downstream channels, on the other hand, run though urban areas, and an industrial scale agricultural production site (Addax), before reaching into the atlantic Ocean near Freetown, the nations's largest city.

Temperature was highest in the peak dry season, when the nation's heat content is usually at the highest (March-April). The warm temperature lingers around untill June. July-August, are the months of heaviest rainfall and cool windy air. Low temperatures in the beginning and end of the year are consistent with the Harmattan season that is characterized by cold dry air across the country.

Turbidity (Figure 8) was highest in the rainy season, especially in the upstream and midstream areas. Tillage agriculture is common in the upstream area and early wet season rains transport most of the sediments into the river. The midstream Area (Magburaka) receives the Tonkolili River, a major tributary that brings in sediments from iron ore and gold mine sites in its upstream. Additionally, there is predominant illicit alluvial gold mining coupled with high human footprint in this area.

Dissolved oxygen (Figure 9) is affected by changes in temperature [34] and this is reflected in the concentration profiles of the two parameters in HR04. The 
DO readings were highest in areas where temperature was lowest, and the same scenario was observed temporally.

The expectation that $\mathrm{PO}_{4}^{3-}$ (Figure 10) would be lowest where and when DO was highest [26] did not hold. The nutrient was highest upstream during the peak rainy season. We suggest that the sources of $\mathrm{PO}_{4}^{3-}$ such as open defecation and rock formations appear to be supplying the nutrient at a rate higher than its ability to become immobilized by bonding with iron (III) in the sediments. This is subject to confirmation in a future phosphorus study in the area.

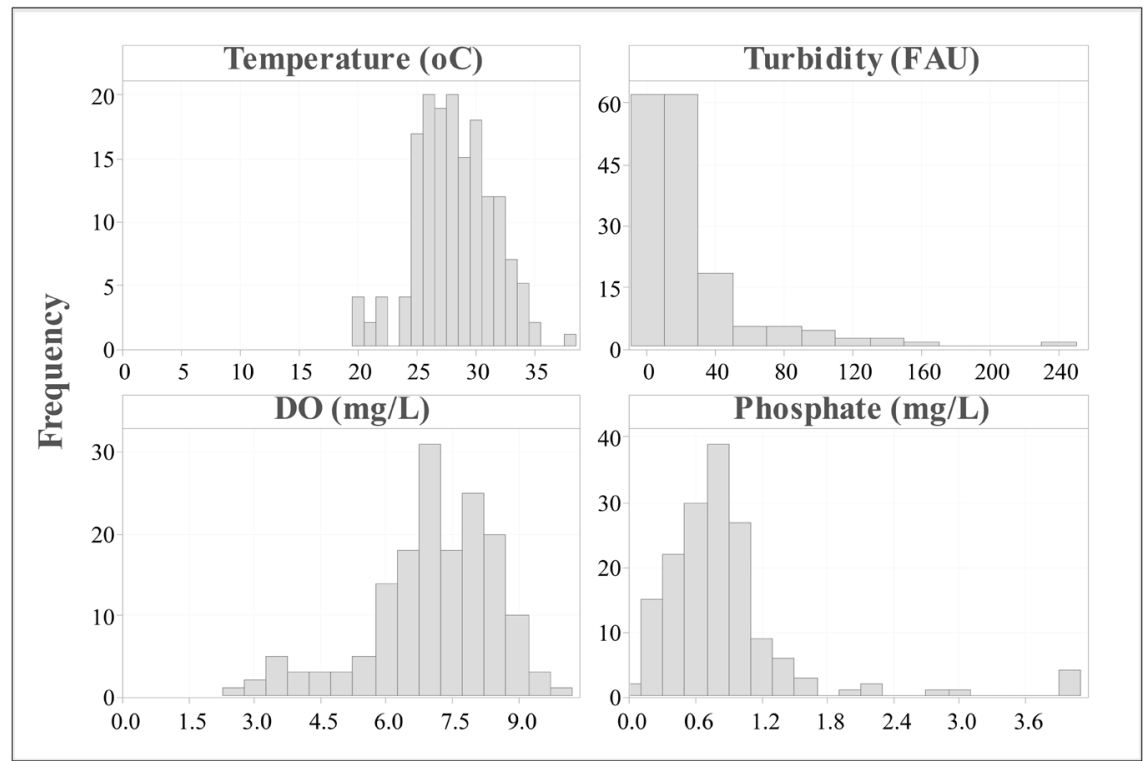

Figure 6. Temperature, turbidity, $\mathrm{DO}$, and $\mathrm{PO}_{4}^{3-}$ at sample sites in HR04. The Frequency in the $y$-axis refers to the number of occurrences of the temperature readings and concentrations of turbidity, $\mathrm{DO}$, and $\mathrm{PO}_{4}^{3-}$ in the $\mathrm{x}$-axis. These data were collected in HR04 at monthly intervals from December 2019 to August 2020.

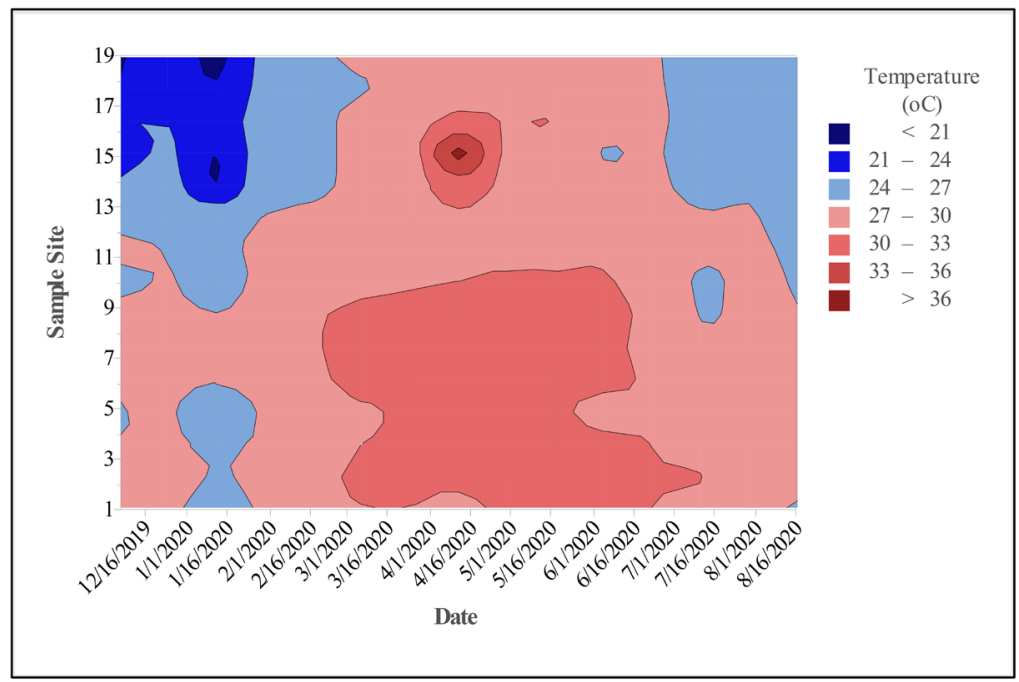

Figure 7. Concentrations of temperature $\left({ }^{\circ} \mathrm{C}\right)$ measured at the various sample sites during sampling visits. 


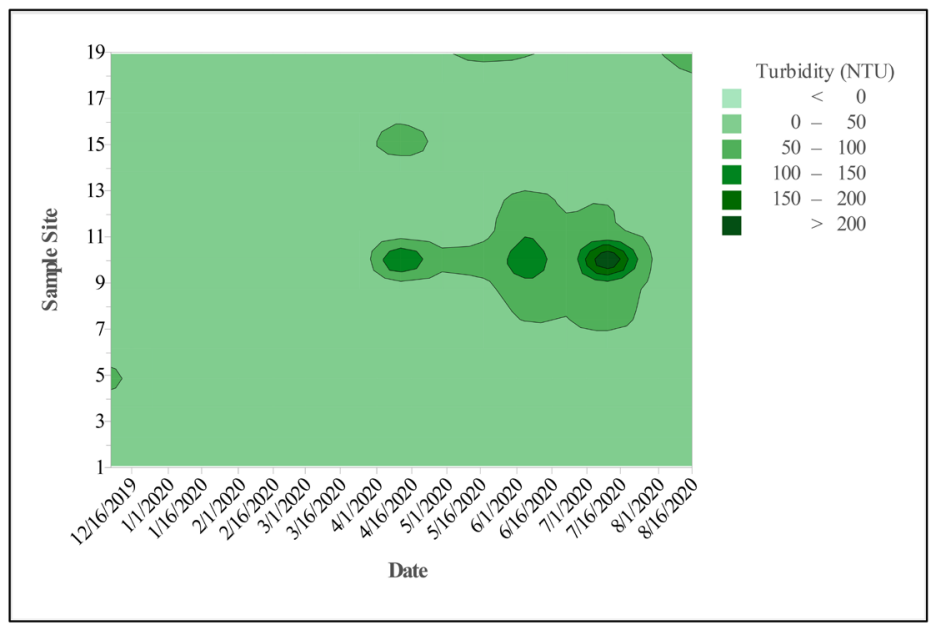

Figure 8. Concentrations of turbidity (NTU) measured at the various sample sites during sampling visits.

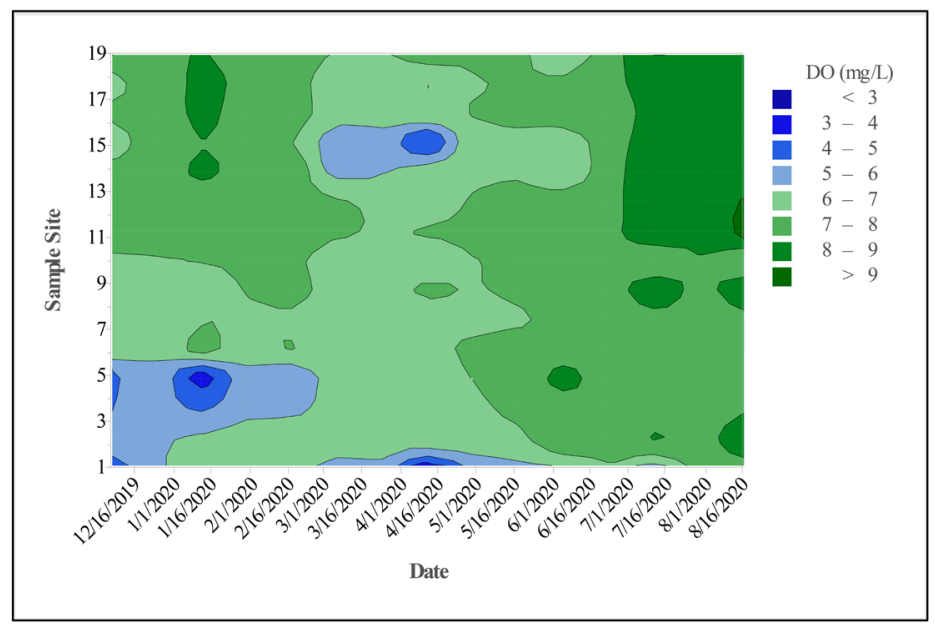

Figure 9. Concentrations of DO $(\mathrm{mg} / \mathrm{L})$ measured at the various sample sites during sampling visits.

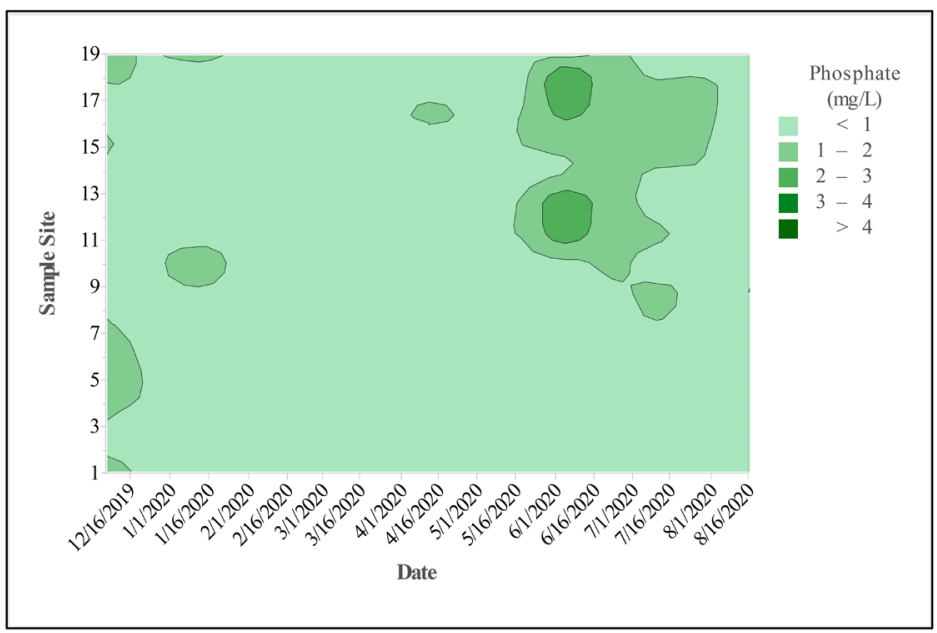

Figure 10. Concentrations $\mathrm{PO}_{4}^{3-} \quad(\mathrm{mg} / \mathrm{L})$ measured at the various sample sites during sampling visits. 
Table 1 presents the WBIDs delineated for HR04, along with their local names, sample IDs, and annual averages of concentrations of temperature, turbidity, $\mathrm{DO}$, and $\mathrm{PO}_{4}^{3-}$. The WBID includes information about the hydrologic region (HR04), the subregion (e.g. W005), the stream level (e.g. L5), and the UID of each stream/river segment. This is an example of how a typical national register of rivers and streams would look like.

\subsubsection{Macroinvertebrates in HR05}

The eight streams sampled appeared to have good water quality based on the presence of macroinvertebrates that are sensitive to pollution. This was expected because of less anticipated human impact on the streams in the area. The communities are small and there is no major industrial activity in the area. Based on temporal variations in macroinvertebrate abundance, stream water quality determination was beyond the scope of this study. Table 2 presents the local names and WBIDs for these streams.

Table 1. The WBIDs of sites sampled for the physical and chemical parameters.

\begin{tabular}{|c|c|c|c|c|c|c|}
\hline \multirow[b]{2}{*}{$\begin{array}{l}\text { Sample } \\
\text { ID }\end{array}$} & \multirow[b]{2}{*}{ Local name } & \multirow[b]{2}{*}{ WBID } & \multicolumn{4}{|c|}{ Annual averages } \\
\hline & & & $\begin{array}{c}\text { Temp } \\
\left({ }^{\circ} \mathrm{C}\right)\end{array}$ & $\begin{array}{l}\text { Turb } \\
\text { (FAU) }\end{array}$ & $\begin{array}{c}\mathrm{DO} \\
(\mathrm{mg} / \mathrm{L})\end{array}$ & $\begin{array}{c}\mathrm{PO}_{4}^{3-} \\
(\mathrm{mg} / \mathrm{L})\end{array}$ \\
\hline 1 & Masafi & HR04W005L5003870 & 28.47 & 10.39 & 5.24 & 0.72 \\
\hline 2 & Rokel Village & HR04W005L1003795 & 30.27 & 6.67 & 7.24 & 0.45 \\
\hline 3 & Mamansu & HR04W005L1003375 & 30.18 & 11.89 & 7.17 & 0.78 \\
\hline 4 & Rokcamp & HR04W005L1003189 & 27.06 & 10.80 & 4.66 & 0.76 \\
\hline 5 & Mane & HR04W004L5002913 & 26.15 & 60.33 & 5.06 & 0.79 \\
\hline 6 & Addax bioenergy company & HR04W004L2002853 & 29.89 & 14.56 & 7.47 & 0.73 \\
\hline 7 & Maken & HR04W003L1003310 & 30.70 & 31.00 & 7.36 & 0.79 \\
\hline 8 & Magburaka Highway & HR04W003L4002642 & 30.44 & 19.67 & 6.01 & 0.69 \\
\hline 9 & Magburaka Intake & HR04W003L3002971 & 29.70 & 30.67 & 7.95 & 0.84 \\
\hline 10 & Bumbuna Bridge Tributary & HR04W001L1002186 & 28.16 & 83.44 & 6.78 & 0.73 \\
\hline 11 & Bumbuna Bridge & HR04W001L5001904 & 27.96 & 33.78 & 8.25 & 0.99 \\
\hline 12 & Bumbuna fall Tributary & HR04W001L2001914 & 28.68 & 1.78 & 7.11 & 0.98 \\
\hline 13 & Bumbuna fall & HR04W001L1001889 & 27.40 & 37.89 & 8.29 & 1.03 \\
\hline 14 & Yebeni Tributary & HR04W001L2001168 & 26.54 & 6.78 & 6.47 & 0.51 \\
\hline 15 & Yilsaia & HR04W001L1001356 & 26.36 & 28.67 & 6.29 & 0.92 \\
\hline 16 & Badala & HR04W001L5001299 & 27.21 & 18.11 & 7.66 & 1.05 \\
\hline 17 & Seli & HR04W001L4001174 & 26.62 & 20.78 & 7.62 & 1.25 \\
\hline 18 & Mamaeli & HR04W001L5001257 & 25.16 & 21.89 & 7.17 & 1.00 \\
\hline 19 & Yirafilaia & HR04W001L5000950 & 25.84 & 37.22 & 7.82 & 0.71 \\
\hline
\end{tabular}


Table 2. The WBIDs of sites sampled for the macroinvertebrate analysis.

\begin{tabular}{cccccc}
\hline Local name & WBID & Common Name & Taxon (Order) & Count & Sensitivity to pollution \\
\hline McDonald & HR05W017L2000263 & Caddisfly & Tricoptera & 6 & Highly sensitive \\
John O'bey & HR05W018L1000333 & Freshwater shrimp & Decopoda & 20 & Highly sensitive \\
Benguma Kapota & HR05W015L1000258 & Water beetles & Coleoptera & 3 & Highly sensitive \\
Kerry Town & HR05W015L1000299 & Dragonfly & Odonata & 1 & Moderately sensitive \\
Mile 13 & HR05W012L1000151 & Dragonfly & Odonata & 1 & Moderately sensitive \\
Tokeh Community & HR05W016L1000230 & Dragonfly & Odonata & 1 & Moderately sensitive \\
Gbongboima & HR05W015L2000208 & Dragonfly & Odonata & 1 & Moderately sensitive \\
Hastings-PTS & HR05W0008L1000178 & Damselfly & Odonata & 1 & Moderately sensitive \\
\hline
\end{tabular}

\subsection{Discussion}

Hydrologists use remote sensing and GIS to study the distribution of water bodies in a region. Remote sensing provides a synoptic-scale view of those water bodies in such detail that allows delineation of their physical, chemical, and biological properties. These properties can be quantified and mapped using GIS tools [15].

This study used ASTERGDEM for the delineation of stream channels using the ArcGIS hydrology tool. Our study corroborates previous efforts that utilized geospatial data and tools to delineate water resources in several sectors. These include water resource applications ranging from delineating flood prone areas (e.g., [35]) to agricultural applications (e.g., [36]).

The ground truth data for four physical and chemical water quality parameters (temperature, turbidity, $\mathrm{DO}$, and $\mathrm{PO}_{4}^{3-}$ ) were consistent with those observed in tropical regions [32] and recommended guidelines [33]. The only exception was $\mathrm{PO}_{4}^{3-}$, which had mean annual concentrations that violated the SDG recommended value of $0.035 \mathrm{mg} / \mathrm{L}$ [33] at all the sample sites (Table 1). The high $\mathrm{PO}_{4}^{3-}$ values suggest further studies to ascertain the sources and associated issues. The ground truth macroinvertebrate taxa were all sensitive to pollution, indicating good water quality. These results are consistent with those found in streams that have fewer human footprints [37]. Delineating the population dynamics of those macroinvertebrates to determine water quality fluctuations was beyond the scope of this study.

The WBID scheme developed in this study will be useful to water resource management practitioners in the study area, Sierra Leone. The National Water Resources Management Agency Act (No. 5 of 2017) provided for the establishment of an agency to manage national water basins and watersheds through the coordination of catchment area management committees and rulemaking for water use and permitting [38]. Implementation of those provisions would be more feasible with the geospatial mapping scheme developed in this study.

Our WBID scheme is scalable in low-income countries because the DEM data are provided globally, and the methods can be used anywhere. Agencies will 
need to calibrate and validate the geospatial data in order to minimize error [39]. The use of citizen science may help save cost in collecting ground truth validation data across a nation or region [40].

\subsection{Conclusions}

The objective of this study was to develop an identification scheme for surface flowing waters in Sierra Leone. We utilized an open-source DEM in ArcGIS to delineate hydrologic regions, subregions, and stream levels in the country. These led to the assignment of WBIDs to the stream segments delineated in the study.

We present two case study analyses for two of the delineated hydrologic regions. In Region 4 (HR04) we utilized the coding system to define WBIDs of 19 stream segments alongside their water quality (temperature, turbidity, DO, and $\mathrm{PO}_{4}^{3-}$ ) data representing designated sample locations. A similar exercise was done for eight streams in Region 5 (HR05) with macroinvertebrate data at designated sample sites within each stream segment.

The coding system developed in this study can be applied in low-income countries to help characterize their waters and inform proper planning for sustainable use of the resource. We utilized an open-source DEM that has a 30-m spatial resolution, which captures major rivers systems and streams over a large area. A finer resolution DEM may be costly although it may give a more detailed characterization of the water systems.

The ArcGIS software package is not an open source compared to the DEM, but it is not as costly to impede license procurement. Additionally, open-source GIS software packages with similar functions are available. The costliest encounter may involve ground truthing to calibrate and confirm existence of all rivers and streams delineated in the study. Water management agencies may significantly reduce this cost by mobilizing citizen scientists to contribute information about existing rivers and streams in their localities.

This study was limited by the amount of available ground-based data and, hence, calibration for accurate location of the modelled rivers and streams was beyond our scope. Also, future efforts could automate the process to codify surface flowing waters and help achieve scalable applications in a faster and easier manner.

This study presents a simple and cost-effective guide to water resource managers in low-income nations for informed decisions regarding their rivers and streams. The coding system will inform allocation of water resources for sustainability in irrigation, mining, recreation, industrial use, water supply, and transportation. These would allow for improved monitoring networks to keep the various sectors updated about water quality, availability, and use. The societal benefit is improved and sustainable utility of natural resources to support economic growth.

\section{Acknowledgements}

The physical and chemical water quality data were provided by the National 
Water Resource Management Agency in Sierra Leone. The Macroinvertebrate data were provided by the Research for Evidence-based and Achievable Decisions Sierra Leone (READ-SL).

\section{Conflicts of Interest}

The authors declare no conflicts of interest regarding the publication of this paper.

\section{References}

[1] Loucks, D.P. and van Beek, E. (2017) Water Resources Planning and Management: An Overview. In: Water Resource Systems Planning and Management, Springer, Berlin, 1-49. https://doi.org/10.1007/978-3-319-44234-1_1

[2] Kareiva, P. and Marvier, M. (2012) What Is Conservation Science? BioScience, 62, 962-969. https://doi.org/10.1525/bio.2012.62.11.5

[3] Alexander, R.B., Boyer, E.W., Smith, R.A., Schwarz, G.E. and Moore, R.B. (2007) The Role of Headwater Streams in Downstream Water Quality. Journal of the American Water Resources Association (JAWRA), 43, 41-59. https://doi.org/10.1111/j.1752-1688.2007.00005.x

[4] Meyer, J.L., Strayer, D.L., Wallace, J.B., Eggert, S.L., Helfman, G.S. and Leonard, N.E. (2007) The Contribution of Headwater Streams to Biodiversity in River Networks. Journal of the American Water Resources Association (JAWRA), 43, 86-103. https://doi.org/10.1111/j.1752-1688.2007.00008.x

[5] Álvarez-Cabria, M., Barquín, J. and Peñas, F.J. (2016) Modelling the Spatial and Seasonal Variability of Water Quality for Entire River Networks: Relationships with Natural and Anthropogenic Factors. Science of the Total Environment, 545-546, 152-162. https://doi.org/10.1016/j.scitotenv.2015.12.109

[6] Eberts, S.M., Woodside, M.D., Landers, M.N. and Wagner, C.R. (2018) Monitoring the Pulse of Our Nation's Rivers and Streams-The U.S. Geological Survey Streamgaging Network. USGS. https://doi.org/10.3133/fs20183081

[7] Theochari, A.-P., Feloni, E., Bournas, A., Karpouzos, D. and Baltas, E. (2019) Multi-Criteria Decision Making and GIS Techniques in the Design of a Stream Gauging Network. World Review of Science, Technology and Sustainable Development, 15, 358-377. https://doi.org/10.1504/WRSTSD.2019.104097

[8] Trigg, S. (2015) Salone Water Security. https://www.salonewatersecurity.com/maps

[9] Schandl, H., Fischer-Kowalski, M., West, J., Giljum, S., Dittrich, M., Eisenmenger, N., Geschke, A., Lieber, M., Wieland, H., Schaffartzik, A., Krausmann, F., Gierlinger, S., Hosking, K., Lenzen, M., Tanikawa, H., Miatto, A. and Fishman, T. (2018) Global Material Flows and Resource Productivity: Forty Years of Evidence. Journal of Industrial Ecology, 22, 827-838. https://doi.org/10.1111/jiec.12626

[10] World Bank (2019) World Bank Country and Lending Groups-Country Classifications. The World Bank Group.

[11] FAO (2005) AQUASTAT-FAO's Global Information System on Water and Agriculture. Food and Agriculture Organization of the United Nations.

[12] Schoul, J., Abbaspour, K.C., Srinivasan, R. and Yang, H. (2008) Estimation of Freshwater Availability in the West African Sub-Continent Using the SWAT Hydrologic Model. Journal of Hydrology, 352, 30-49.

https://doi.org/10.1016/j.jhydrol.2007.12.025 
[13] Nicol, D.S.W.H., Fyfe, C. and Sesay, S.M. (1999) Sierra Leone, Encyclopedia Britanica.

[14] Rai, P.K., Mohan, K., Mishra, S., Ahmad, A. and Mishra, V.A. (2017) A GIS-Based Approach in Drainage Morphometric Analysis of Kanhar River Basin, India. Applied Water Science, 7, 217-232. https://doi.org/10.1007/s13201-014-0238-y

[15] Amatulli, G., Domisch, S., Kiesel, J., Sethi, T., Yamazaki, D. and Raymond, P. (2018) High-Resolution Stream Network Delineation Using Digital Elevation Models: Assessing the Spatial Accuracy. https://doi.org/10.7287/peerj.preprints.27109

[16] Abrams, M., Crippen, R. and Fujisada, H. (2020) ASTER Global Digital Elevation Model (GDEM) and ASTER Global Water Body Dataset (ASTWBD). Remote Sensing, 12, 1156. https://doi.org/10.3390/rs12071156

[17] NRCS-USDSA (2007) Watersheds, Hydrologic Units, Hydrologic Unit Codes, Watershed Approach, and Rapid Watershed Assessments. https://www.nrcs.usda.gov/Internet/FSE DOCUMENTS/stelprdb1042207.pdf

[18] Day, S.J., Carter, R., Dumble, P., Juana, M., Kamara, I. and Mansaray, A. (2015) Strategy for Water Security Planning Volume I. Ministry of Water Resources Sierra Leone, Freetown.

[19] SSL (2016) Sierra Leone 2015 Population and Housing Census-Provisional Results. Statistics Sierra Leone, Freetown.

[20] NASA (2013) EARTHDATA. National Aeronautics and Space Administration.

[21] ESRI (2016) ArcMap-An Overview of the Hydrology Toolset. Environmental Systems Research Institute, Inc., Redlands.

https://desktop.arcgis.com/en/arcmap/10.3/tools/spatial-analyst-toolbox/an-overvie w-of-the-hydrology-tools.htm

[22] Haward, A.D. (1967) Watershed Drainage Patterns. AAPG Bulletin, 51, 46-59.

[23] Caissie, D. (2006) The Thermal Regime of Rivers: A Review. Freshwater Biology, 51, 1389-1406. https://doi.org/10.1111/j.1365-2427.2006.01597.x

[24] Borch, T., Kretzschmar, R., Kappler, A., Cappellen, P.V., Ginder-Vogel, M., Vogelin, A. and Campbell, K. (2010) Biogeochemical Redox Processes and Their Impact on Contaminant Dynamics. Environmental Science \& Technology, 44, 15-23. https://doi.org/10.1021/es9026248

[25] Lind, O.T., Doyle, R., Vodopich, D.S., Trotter, B.G., Limon, J.G. and Dcivalos-Lind, L. (1992) Clay Turbidity: Regulation of Phytoplankton Production in a Large, $\mathrm{Nu}$ trient-Rich Tropical Lake. Limnology and Oceanography, 37, 549-565. https://doi.org/10.4319/lo.1992.37.3.0549

[26] Herndon, E.M., Kinsman-Costello, L., Duroe, K.A., Mills, J., Kane, E.S., Sebestyen, S.D., Thompson, A.A. and Wullschleger, S.D. (2019) Iron (Oxyhydr)Oxides Serve as Phosphate Traps in Tundra and Boreal Peat Soils. JGR Biogeosciences, 124, $227-$ 246. https://doi.org/10.1029/2018/G004776

[27] Patang, F., Soegianto, A. and Hariyanto, S. (2018) Benthic Macroinvertebrates Diversity as Bioindicator of Water Quality of Some Rivers in East Kalimantan, Indonesia. International Journal of Ecology, 2018, Article ID: 5129421. https://doi.org/10.1155/2018/5129421

[28] Tamiru, S.M. (2019) Macroinvertebrates as Indicators of the Water Quality of River Shinta, Gondar, Ethiopia. Sustainable Water Resources Management, 5, 1227-1241. https://doi.org/10.1007/s40899-018-0297-6

[29] Gonçalves, F.B. and de Menezes, M.S. (2011) A Comparative Analysis of Biotic Indices That Use Macroinvertebrates to Assess Water Quality in a Coastal River of 
Paraná State, Southern Brazil. Biota Neotropica, 11, 27-36. https://doi.org/10.1590/S1676-06032011000400002

[30] Campbell, E.Y., Merritt, R.W., Cummins, K.W., Benbow, M.E. and Benbow, M.E. (2012) Spatial and Temporal Variability of Macroinvertebrates in Spawning and Non-Spawning Habitats during a Salmon Run in Southeast Alaska. PLoS ONE, 7, e39254. https://doi.org/10.1371/journal.pone.0039254

[31] Zhang, Z.-Q. and Shear, W.A. (2007) Linnaeus Tercentenary and Invertebrate Taxonomy: An Introduction. Zootaxa, 1668, 7-10. https://doi.org/10.11646/zootaxa.1668.1.2

[32] Syvitski, J., Cohen, S., Miara, A. and Best, J. (2019) River Temperature and the Thermal-Dynamic Transport of Sediment. Global and Planetary Change, 178, 168 183. https://doi.org/10.1016/j.gloplacha.2019.04.011

[33] Warner, S. (2020) SDG Indicator 6.3.2 Technical Guidance Document No. 2: Target Values. UNEP GEMS/Water Capacity Development Centre, University College Cork, Cork.

[34] Null, S.E., Mouzon, N.R. and Elmore, L.R. (2017) Dissolved Oxygen, Stream Temperature, and Fish Habitat Response to Environmental Water Purchases. Journal of Environmental Management, 197, 559-570. https://doi.org/10.1016/j.jenvman.2017.04.016

[35] Manfreda, S., Di Leo, M. and Sole, A. (2011) Detection of Flood-Prone Areas Using Digital Elevation Models. Journal of Hydrologic Engineering, 16, 781-790. https://doi.org/10.1061/(ASCE)HE.1943-5584.0000367

[36] Mokarram, M. and Hojati, M. (2017) Morphometric Analysis of Stream as One of Resources for Agricultural Lands Irrigation Using High Spatial Resolution of Digital Elevation Model (DEM). Computers and Electronics in Agriculture, 142, 190-200. https://doi.org/10.1016/j.compag.2017.09.001

[37] Chellaiah, D. and Yule, C.M. (2018) Riparian Buffers Mitigate Impacts of Oil Palm Plantations on Aquatic Macroinvertebrate Community Structure in Tropical Streams of Borneo. Ecological Indicators, 95, 53-62. https://doi.org/10.1016/j.ecolind.2018.07.025

[38] InforMEA (2017) National Water Resources Management Agency Act (No. 5 of 2017). Access Information on Multilateral Environmental Agreements. https://www.informea.org/en/legislation/national-water-resources-management-ag ency-act-no-5-2017

[39] Wechsler, S.P. (2007) Uncertainties Associated with Digital Elevation Models for Hydrologic Applications: A Review. Hydrology and Earth System Sciences Discussions, 11, 1481-1500. https://doi.org/10.5194/hess-11-1481-2007

[40] Rambonnet, L., Vink, S.C., Land-Zandstra, A.M. and Bosker, T. (2019) Making Citizen Science Count: Best Practices and Challenges of Citizen Science Projects on Plastics in Aquatic Environments. Marine Pollution Bulletin, 145, 271-277. https://doi.org/10.1016/j.marpolbul.2019.05.056 